\title{
Discovery of MK-8718, an HIV Protease Inhibitor Containing a Novel Morpholine Aspartate Binding Group
}

Christopher J. Bungard, ${ }^{* a}$ Peter D. Williams, ${ }^{a}$ Jeanine E. Ballard, ${ }^{a}$ David J. Bennett, ${ }^{a}$ Christian Beaulieu, ${ }^{\mathrm{b}}$ Carolyn Bahnck-Teets, ${ }^{\mathrm{a}}$ Steve S. Carroll, ${ }^{\mathrm{a}}$ Ronald K. Chang, ${ }^{\mathrm{a}}$ David C. Dubost, ${ }^{\mathrm{a}}$ John F. Fay, ${ }^{\mathrm{a}}$ Tracy L. Diamond, ${ }^{\mathrm{a}}$ Thomas J. Greshock, ${ }^{\mathrm{a}}$ Li Hao, M. Katharine Holloway, ${ }^{\text {a }}$ Peter J. Felock, Jennifer J. Gesell, ${ }^{\mathrm{a}}$ Hua-Poo Su, ${ }^{\mathrm{a}}$ Jesse J. Manikowski, ${ }^{\mathrm{a}}$ Daniel J. McKay, ${ }^{b}$ Mike Miller, ${ }^{a}$ Xu Min, ${ }^{a}$ Carmela Molinaro, ${ }^{a}$ Oscar M. Moradei, ${ }^{b}$ Philippe G. Nantermet, ${ }^{\mathrm{a}}$ Christian Nadeau, ${ }^{\mathrm{b}}$ Rosa I. Sanchez, ${ }^{\mathrm{a}}$ Tummanapalli Satyanarayana, ${ }^{\mathrm{c}}$ William D. Shipe, ${ }^{\text {a }}$ Sanjay K. Singh, ${ }^{\mathrm{c}}$ Vouy L. Truong, ${ }^{\mathrm{b}}$ Sivalenka Vijayasaradhi, ${ }^{\mathrm{c}}$ Catherine M. Wiscount, ${ }^{a}$ Joseph P. Vacca, ${ }^{b}$ Sheldon N. Crane, ${ }^{b}$ and John A. McCauley. ${ }^{a}$

aMerck Research Laboratories, 770 Sumneytown Pike, PO Box 4, West Point, PA 19486, USA

${ }^{b}$ Merck Frosst Centre for Therapeutic Research, 16711 TransCanada Highway, Kirkland, Quebec, Canada, $\mathrm{H}_{9} \mathrm{H}_{3} \mathrm{~L} 1$

'Albany Molecular Research Singapore Research Center, 61 Science Park Road \#05-01, The Galen Singapore Science Park II, Singapore 117525

Corresponding Author

* E-mail: christopher_bungard@merck.com

Phone: 215-652-5002

\section{Assay Protocols}

Assay for Inhibition of Microbial Expressed HIV Protease

Studies of the inhibition of the wildtype HIV-1 protease (which was expressed in Escherichia coli) were carried out with a peptide substrate [Val-Ser-Gln-Asn-( $\beta$ naphtyl)Ala-Pro-Ile-Val (SEQ ID NO 1)]. The inhibitor was first preincubated with the HIV-1 protease (wild type) enzyme in assay buffer (50 mM sodium acetate, $\mathrm{pH} 5 \cdot 5,100 \mathrm{mM}$ $\mathrm{NaCl}$, and o.1\% BSA) for 30 minutes at room temperature. Substrate was added to 400 micromolar in a total volume of 20 microliters containing 20 picomolar HIV-1 protease (final) and the reaction is incubated for 1 hour at $30^{\circ} \mathrm{C}$. The reaction was quenched with the addition of formic acid and indinavir to $0.012 \%$ and $150 \mathrm{nM}$ final concentrations, respectively. Product formation was determined after separation of product and substrate on a Zorbax Eclipse XDB-C18 column connected to an API 4000 mass spectrometer (Applied Biosystems) with multiple reaction monitoring (transitions were $644.5 / 428.9$ and $615.4 / 422.2\left(\mathrm{M}_{1} / \mathrm{M}_{3}\right)$ for product and indinavir 
respectively). The extent of inhibition of the reaction was determined from the peak area of the products. Analysis of the products, independently synthesized, provided quantitation standards and confirmation of the product composition. Representative compounds of the present invention exhibit inhibition of HIV-1 protease in this assay.

\section{Antiviral Assays in Cell Culture}

Antiviral potency in a multiple round HIV-1 infection assay was carried out as follows. The assay was performed using MT-4 human T-lymphoid cells. MT-4 cells (2.5 x 105 cells per ml) were infected at a multiplicity of infection of $\leq 0.01$ and incubated overnight in RPMI 1640 culture medium containing $10 \%$ fetal bovine serum. The infected cells were then washed twice in fresh culture medium and resuspended in RPMI 1640 containing $50 \%$ normal human serum at $4 \times 105$ cells/ml and seeded into 384-well cell culture plates at 12,00o cells per well. Serial 1:2 dilutions of the test compounds were added to the wells. The test cultures were incubated for an additional $72 \mathrm{~h}$ at $37^{\circ} \mathrm{C}$ at which time virus levels were assayed. $\mathrm{IC}_{95}$ values were determined by non-linear 4-parameter curve fitting.

\section{Synthesis of $9 b-9 j$}

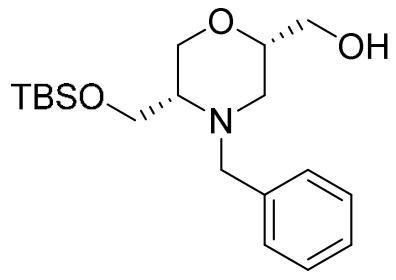

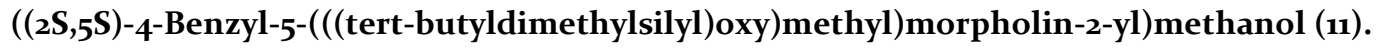

Lithium perchlorate (18.3 g, $172 \mathrm{mmol}$ ) was added portionwise (caution exotherm!) to a solution of (S)-2(benzylamino)-3-((tert-butyldimethylsilyl)oxy)propan-1-ol (39.0 g, $132 \mathrm{mmol}$ ) and (R)-(-)-epichlorohydrin (15.9 g, $172 \mathrm{mmol})$ in toluene $(400 \mathrm{ml})$ at ambient temperature. The resulting reaction was stirred at ambient temperature for $48 \mathrm{~h}$. MeOH (100 ml) was added followed by slow addition of $\mathrm{NaOMe}(4 \mathrm{M}, 83 \mathrm{~mL})$ in $\mathrm{MeOH}$. The resulting reaction was stirred at ambient temperature for $48 \mathrm{~h}$. The reaction was quenched with sat. aq. $\mathrm{NH}_{4} \mathrm{Cl}$, and the crude product was extracted with EtOAc $\left(\mathrm{x}_{3}\right)$. The combined organic fractions washed with brine, dried 
over $\mathrm{MgSO}_{4}$, and concentrated in vacuo. Purification on silica gel, eluting with a gradient of 10 to 50 \% EtOAc in hexanes, afforded the title compound (25 g, $54 \%$ ) as a colorless gum. ${ }^{1} \mathrm{H}$ NMR (40o MHz, Acetone-d6) $\delta 7.39$ (d, J $=7.1 \mathrm{~Hz}, 2 \mathrm{H}), 7.36-7.29(\mathrm{~m}, 2 \mathrm{H}), 7.28-7.20(\mathrm{~m}, 1 \mathrm{H}), 4.03-3.95\left(\mathrm{~m},{ }_{3} \mathrm{H}\right), 3.92(\mathrm{~d}, \mathrm{~J}=13.7 \mathrm{~Hz}, 1 \mathrm{H}), 3.78(\mathrm{~d}, \mathrm{~J}=13.7$ $\mathrm{Hz}, 1 \mathrm{H}), 3.65(\mathrm{dd}, \mathrm{J}=2.8,11.0 \mathrm{~Hz}, 1 \mathrm{H}), 3.61-3.51(\mathrm{~m}, 3 \mathrm{H}), 3.5 \mathrm{O}-3.40(\mathrm{~m}, 1 \mathrm{H}), 2.73-2.64(\mathrm{~m}, 1 \mathrm{H}), 2.55-2.48(\mathrm{~m}$, 2H), $0.91(\mathrm{~s}, 9 \mathrm{H}), 0.09\left(\mathrm{~s},{ }_{3} \mathrm{H}\right), 0.07(\mathrm{~s}, 3 \mathrm{H})$; MS (ESI): $m / z=352.1\left(\mathrm{MH}^{+}\right)$.

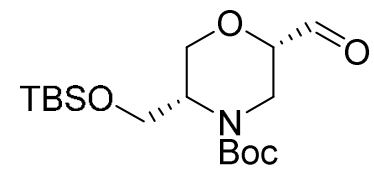

tert-Butyl (2S,5S)-5-(((tert-butyldimethylsilyl)oxy)methyl)-2-formylmorpholine-4-carboxylate (12). ((2S, 5 S)-4-Benzyl-5-(((tert-butyldimethylsilyl)oxy)methyl)morpholin-2-yl)methanol (11) (50 g, 142 mmol), Boc ${ }_{2} \mathrm{O}$ (40 ml, $171 \mathrm{mmol}), \mathrm{NEt}_{3}(2 \mathrm{O} \mathrm{ml}, 142 \mathrm{mmol})$ and $\mathrm{PdOH}_{2}(2 \mathrm{O}, 28.4 \mathrm{mmol})$ were suspended in Ethanol (50o ml) under nitrogen in a Parr shaker appartus. The reaction was evacuated and backfilled with hydrogen gas ( $\left.\mathrm{x}_{3}\right)$ and shaken overnight at 45 psi hydrogen. The reaction was evacuated and backfilled with nitrogen ( $x_{3}$ ) and the resulting suspension filtered through Solka-Floc ${ }^{\circledast}$. The filtrate was diluted with EtOAc and the solution washed with water ( $\mathrm{x}_{3}$ ), then dried over $\mathrm{Na}_{2} \mathrm{SO}_{4}$ and concentrated in vacuo. Purification on silica gel, eluting with a gradient of 5 to $40 \%$ EtOAc in hexanes, afforded the tert-butyl $(2 \mathrm{~S}, 5 \mathrm{~S})-5-(($ tert-butyldimethylsilyl)oxy)methyl)2-(hydroxymethyl)morpholine-4-carboxylate $(51 \mathrm{~g})$ as a colorless gum. DMSO (22 $\mathrm{ml}, 312 \mathrm{mmol})$ was dissolved in $\mathrm{CH}_{2} \mathrm{Cl}_{2}(360 \mathrm{ml})$ and the resulting solution cooled to $-78^{\circ} \mathrm{C}$. Oxalyl chloride $(21 \mathrm{ml}, 241 \mathrm{mmol})$ was added dropwise at a rate so as the internal temperature did not exceed $-55^{\circ} \mathrm{C}$. The resulting reaction was stirred at $-78^{\circ} \mathrm{C}$ for 30 min. tert-Butyl (2S,5S)-5-(((tert-butyldimethylsilyl)oxy)methyl)-2-(hydroxymethyl)morpholine-4-carboxylate (51 g, $142 \mathrm{mmol}$ ) was dissolved in $\mathrm{CH}_{2} \mathrm{Cl}_{2}(154 \mathrm{ml})$ and added dropwise at a rate so as the internal temperature did not exceed $-60^{\circ} \mathrm{C}$. The resulting reaction was stirred at $-78^{\circ} \mathrm{C}$ for $30 \mathrm{~min}$, then a further $1 \mathrm{~h}$ between $-6 \mathrm{o}$ and $-45^{\circ} \mathrm{C}$. The reaction was cooled to $-78^{\circ} \mathrm{C}$ and $\mathrm{NEt}_{3}$ (99 $\mathrm{ml}, 709 \mathrm{mmol}$ ) was added dropwise at a rate so as the internal temperature did not exceed $-60^{\circ} \mathrm{C}$. The resulting reaction was warmed directly to $\mathrm{o}^{\circ} \mathrm{C}$ and stirred for $1 \mathrm{~h}$. The reaction was quenched with water and the crude product was extracted with $\mathrm{CH}_{2} \mathrm{Cl}_{2}\left(\mathrm{x}_{3}\right)$. The combined organic fractions washed with water, brine, dried over $\mathrm{Na}_{2} \mathrm{SO}_{4}$, and concentrated in vacuo to afford crude title compound, 
tert-butyl (2S,5S)-5-(((tert-butyldimethylsilyl)oxy)methyl)-2-formylmorpholine-4-carboxylate (51 g, 100 \%) which was used directly without further purification.

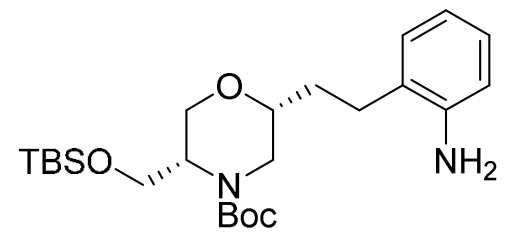

tert-Butyl (2R,5S)-2-(2-aminophenethyl)-5-(((tert-butyldimethylsilyl)oxy)methyl)morpholine-4-carboxylate (13).

(2-Nitrobenzyl)triphenylphosphonium bromide monohydrate (77 g, $156 \mathrm{mmol}), \mathrm{K}_{2} \mathrm{CO}_{3}(39.2 \mathrm{~g}, 284 \mathrm{mmol})$ and 18 -crown$6(3.75 \mathrm{~g}, 14.19 \mathrm{mmol})$ were combined in DME $(500 \mathrm{ml})$ and the reaction stirred at ambient temperature for $5 \mathrm{~min}$. A solution of tert-butyl (2S,5S)-5-(((tert-butyldimethylsilyl)oxy)methyl)-2-formylmorpholine-4-carboxylate (12) (51 g, 142 mmol) in DME $(500 \mathrm{ml})$ was added and the resulting reaction stirred overnight at ambient temperature. The resulting suspension was filtered through solka-floc ${ }^{\circledR}$ and the filtrate concentrated in vacuo. Purification on silica gel, eluting with a gradient of 10 to $30 \%$ EtOAc in hexanes, afforded tert-butyl (2R,5S)-5-(((tert-butyldimethylsilyl)oxy)methyl)-2-((E and Z)-2-nitrostyryl)morpholine-4-carboxylate (63 g, $92 \%$ ) (mixture of $E$ and $Z$ isomers) as a colorless gum. MS (ESI): $\mathrm{m} / \mathrm{z}=$ $501.4(\mathrm{M}+\mathrm{Na})$. The mixture of olefin isomers $(63 \mathrm{~g})$ was dissolved in nitrogen degassed EtOH and added to a suspension of $10 \% \mathrm{Pd} / \mathrm{C}(11 \mathrm{~g})$ in $\mathrm{EtOH}$, total $\mathrm{EtOH}(1000 \mathrm{ml})$. The reaction was evacuated and backfilled with hydrogen and shaken at 50 psi on a Parr reactor overnight.. The reaction was evacuated and backfilled with nitrogen, filtered through a solka-floc ${ }^{\circledR}$, and concentrated in vacuo to afford the title compound (57 g, $\left.97 \%\right)$ as a colorless gum. ${ }^{1} \mathrm{H}$ NMR (50o MHz, Acetone-d6) $\delta 6.99(\mathrm{~d}, \mathrm{~J}=7 \cdot 3 \mathrm{~Hz}, 1 \mathrm{H}), 6.94(\mathrm{t}, \mathrm{J}=7.7 \mathrm{~Hz}, 1 \mathrm{H}), 6.70(\mathrm{~d}, \mathrm{~J}=7 \cdot 9$ $\mathrm{Hz}, 1 \mathrm{H}), 6.58(\mathrm{t}, \mathrm{J}=7.4 \mathrm{~Hz}, 1 \mathrm{H}), 4.46(\mathrm{~s}, 1 \mathrm{H}), 4.11(\mathrm{t}, \mathrm{J}=11.7 \mathrm{~Hz}, 1 \mathrm{H}), 3.98-3.70(\mathrm{~m}, 4 \mathrm{H}), 3.68-3.60(\mathrm{~m}, 1 \mathrm{H}), 3.53$ $(\mathrm{dd}, \mathrm{J}=11.6,2.9 \mathrm{~Hz}, 1 \mathrm{H}), 3.37-3.27(\mathrm{~m}, 1 \mathrm{H}), 2.85-2.57(\mathrm{~m}, 3 \mathrm{H}), 1.79-1.69(\mathrm{~m}, 2 \mathrm{H}), 1.45(\mathrm{~s}, 9 \mathrm{H}), 0.94(\mathrm{~s}, 9 \mathrm{H}), 0.17-$ $0.10(\mathrm{~m}, 6 \mathrm{H}) ; \mathrm{MS}(\mathrm{ESI}): \mathrm{m} / \mathrm{z}=473.2(\mathrm{M}+\mathrm{Na})$. 


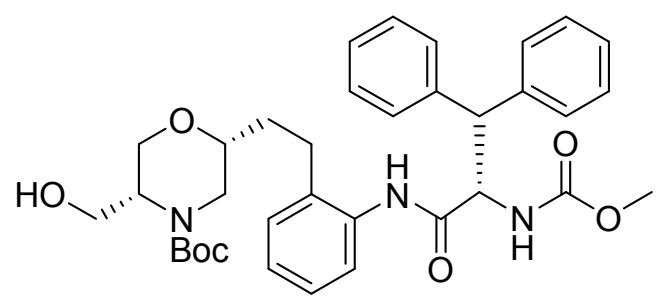

tert-Butyl (2R,5R)-5-(hydroxymethyl)-2-(2-((S)-2-((methoxycarbonyl)amino)-3,3diphenylpropanamido)phenethyl)morpholine-4-carboxylate (15).

2,6-Lutidine was added to a solution of tert-Butyl $\quad(2 \mathrm{R}, 5 \mathrm{~S})-2$-(2-aminophenethyl)-5- $((($ tertbutyldimethylsilyl)oxy)methyl)morpholine-4-carboxylate (13) (4.59 g, 10.2 mmol), HATU ${ }^{\circledR}$ (5.42 g, 14.3 mmol), and (S)-2-((methoxycarbonyl)amino)-3,3-diphenylpropanoic acid (3.66 g, $12.2 \mathrm{mmol})$ in DMF (70 ml) at ambient temperature and the resulting reaction stirred at this temperature overnight. The reaction was quenched with sat. aq. $\mathrm{NaHCO}_{3}$, and the crude product was extracted with EtOAc (x3). The combined organic fractions washed with $1 \mathrm{M} \mathrm{HCl}$, brine, dried over $\mathrm{MgSO}_{4}$, and concentrated in vacuo. Purification on silica gel, eluting with a gradient of o to $50 \%$ EtOAc in hexanes, afforded tert-butyl (2R,5S)-5-((tert-butyldimethylsilyl)oxy)methyl)-2-(2((S)-2-((methoxycarbonyl)amino)-3,3-diphenylpropanamido)phenethyl)morpholine-4-carboxylate (3.95 g, 53\%). MS (ESI): $\mathrm{m} / \mathrm{z}=632.2(\mathrm{M}+2 \mathrm{H}-\mathrm{Boc})$. The TBS ether (1.10 g, $1.50 \mathrm{mmol})$ was dissolved in THF (8 ml) and a $1 \mathrm{M}$ solution of TBAF in THF ( $3 \mathrm{ml}$ ) was added dropwise at ambient temperature and the reaction stirred for 1 hour. The reaction was quenched with water, and the crude product was extracted with EtOAc ( $\left.x_{3}\right)$. The combined organic fractions washed with brine, dried over $\mathrm{MgSO}_{4}$, and concentrated in vacuo. Purification on silica gel, eluting with a gradient of 10 to $100 \%$ EtOAc in hexanes, afforded the title compound (o.780 g, $84 \%) .{ }^{1} \mathrm{H}$ NMR (500 MHz, Chloroform-d) $\delta 8.19-8.00(\mathrm{~m}, 1 \mathrm{H}), 7.70-7.60(\mathrm{~m}, 1 \mathrm{H}), 7.40-7.04(\mathrm{~m}, 12 \mathrm{H}), 5.37-5.21(\mathrm{~m}, 1 \mathrm{H}), 5.10-$ $4.95(\mathrm{~m}, 1 \mathrm{H}), 4.71-4.54(\mathrm{~m}, 1 \mathrm{H}), 4.25-4.05(\mathrm{~m}, 1 \mathrm{H}), 4.00-3.50(\mathrm{~m}, 6 \mathrm{H}), 3.12-2.99(\mathrm{~m}, 1 \mathrm{H}), 2.67-2.90(\mathrm{~m}, 1 \mathrm{H})$, $2.46-2.82(\mathrm{~m}, 1 \mathrm{H}), 2.26-2.10(\mathrm{~m}, 1 \mathrm{H}), 1.69-1.51\left(\mathrm{~m},{ }_{3} \mathrm{H}\right), 1.47(\mathrm{~s}, 9 \mathrm{H})$. 
<smiles>[R]NC(=O)OC[C@H]1CNC[C@H](CCc2ccccc2NC(=O)[C@H](NC(=O)OC)C(c2ccccc2)c2ccccc2)OC1</smiles>

\section{General procedure for the preparation of amines $9 b-9 j$ in Table 1.}

tert-Butyl $\quad(2 \mathrm{R}, 5 \mathrm{R})-5$-(hydroxymethyl)-2-(2-((S)-2-((methoxycarbonyl)amino)-3,3-diphenylpropanamido) phenethyl)morpholine-4-carboxylate (15) (1 eq.) and CDI (2.05 eq) were dissolved in dry Pyridine (0.04 M) and the resulting solution heated at $50{ }^{\circ} \mathrm{C}$ for $30 \mathrm{~min}$. The appropriate amine (6 eq.) was added and the resulting reaction heated at $50^{\circ} \mathrm{C}$ overnight. The mixture was diluted with EtOAc, washed with $5 \%$ aq. $\mathrm{KHSO}_{4}$, sat. $\mathrm{NaHCO}_{3}$, dried over $\mathrm{Na}_{2} \mathrm{SO}_{4}$, filtered and concentrated. The residues were purified on silica gel eluting with a gradient of o to $5 \% \mathrm{MeOH}$ in DCM. The resulting Boc-protected Morpholines were deprotected by stirring with a 1:1 mixture of DCM:TFA at ambient temperature for 1 hour. The reaction mixtures were concentrated in vacuo then co-evaporated with heptane ( $\mathrm{x} 2)$ and triturated with ether to afford the products shown in table 1 as TFA salts. Alternatively the TFA salt could be neutralized with sat. aq. $\mathrm{NaHCO}_{3}$, extracted with EtOAc, dried over $\mathrm{MgSO}_{4}$, concentrated in vacuo then purified on silica gel eluting with a gradient of o to $5 \% \mathrm{MeOH}$ in DCM to afford the products shown in table 1. 
Table 1. Amine coupling partners and MS data for $9 \mathrm{~b}-9 \mathrm{j}$.

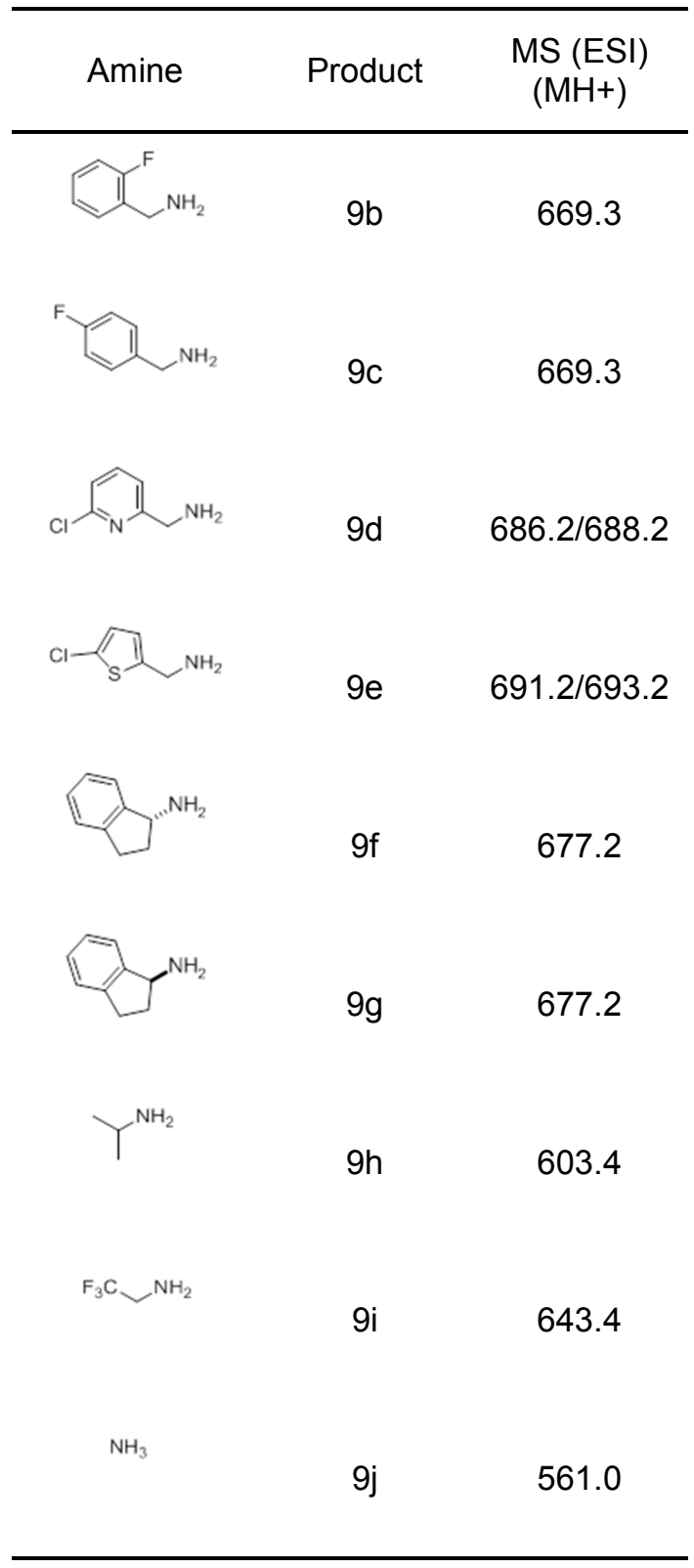




\section{Synthesis of MK-8718}

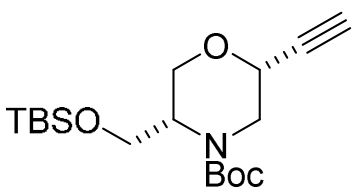

tert-Butyl (2R,5S)-5-(((tert-butyldimethylsilyl)oxy)methyl)-2-ethynylmorpholine-4-carboxylate (19).

Dimethyl (1-diazo-2-oxopropyl)phosphonate $(3.90 \mathrm{ml}, 26.0 \mathrm{mmol})$ was added to tert-butyl $\left.{ }_{2} \mathrm{~S},{ }_{5} \mathrm{~S}\right){ }_{5}-((($ tertbutyldimethylsilyl)oxy)methyl)-2-formylmorpholine-4-carboxylate (12) $(7.78 \mathrm{~g}, 21.6 \mathrm{mmol})$ and $\mathrm{K}_{2} \mathrm{CO}_{3}(5.98 \mathrm{~g}$, $43.3 \mathrm{mmol})$ in anhydrous $\mathrm{MeOH}(216 \mathrm{ml})$ at ambient temperature. The resulting reaction was stirred for $2 \mathrm{~h}$ at ambient temperature, then filtered and the $\mathrm{MeOH}$ removed in vacuo. Sat. aq. $\mathrm{KH}_{2} \mathrm{PO}_{4}$ was added and the mixture was extracted with EtOAc ( $x_{3}$ ). The combined organic fractions were dried over $\mathrm{MgSO}_{4}$ and concentrated in vacuo. Purification on silica gel, eluting with a gradient of o to $30 \%$ EtOAc in hexanes, afforded the title compound (4.6 g, 6o \%) as a colorless gum. ${ }^{1} \mathrm{H}$ NMR $(500 \mathrm{MHz}, \mathrm{DMSO}-\mathrm{d} 6) \delta 4.16(\mathrm{~d}, \mathrm{~J}=10.9 \mathrm{~Hz}, 1 \mathrm{H}), 3.85(\mathrm{~d}, \mathrm{~J}=$ $11.8 \mathrm{~Hz}, 1 \mathrm{H}), 3.90-3.67(\mathrm{~m}, 3 \mathrm{H}), 3.6 \mathrm{o}-3.45(\mathrm{~m}, 3 \mathrm{H}), 3.02-2.78(\mathrm{br} \mathrm{m}, 1 \mathrm{H}), 1.4 \mathrm{o}(\mathrm{s}, 9 \mathrm{H}), 0.87(\mathrm{~s}, 9 \mathrm{H}), 0.05(\mathrm{~s}, 6 \mathrm{H})$; MS (ESI): $m / z=256.01(\mathrm{M}+\mathrm{H}-\mathrm{Boc})$.<smiles>CC(C)(C)O[C@H]1CO[C@@H](CCc2c(N)cncc2F)CN1C(=O)O</smiles>

tert-Butyl (2R,5S)-2-(2-(3-amino-5-fluoropyridin-4-yl)ethyl)-5-((tertbutyldimethylsilyl)oxy)methyl)morpholine-4-carboxylate (21). tert-Butyl $\left({ }_{2} \mathrm{R}, 5 \mathrm{~S}\right)-5-(($ tert-butyldimethylsilyl)oxy)methyl)-2-ethynylmorpholine-4-carboxylate (19) (6.80 g, 19.1 mmol), 5-fluoro-4-iodopyridin-3-amine (4.55 g, $19.1 \mathrm{mmol}$ ), $\left(\mathrm{PPh}_{3}\right)_{2} \mathrm{PdCl}_{2}$ (o.940 g, 1.34 mmol), $\mathrm{NEt}_{3}$ (8o ml, 574 mmol), and $\mathrm{CuI}(0.364 \mathrm{~g}, 1.91 \mathrm{mmol})$ were heated at $7 \mathrm{O}^{\circ} \mathrm{C}$ overnight. The reaction was quenched with sat. aq. $\mathrm{KH}_{2} \mathrm{PO}_{4}$, and the crude product was extracted with EtOAc $\left(\mathrm{x}_{3}\right)$. The combined organic fractions were dried over $\mathrm{MgSO}_{4}$, and concentrated in vacuo. Purification on silica gel, eluting with a gradient of o to $100 \%$ EtOAc in hexanes, afforded tert-butyl $\quad(2 \mathrm{R}, 5 \mathrm{~S})-2-((3-$ amino-5-fluoropyridin-4-yl)ethynyl)-5-((tertbutyldimethylsilyl)oxy)methyl)morpholine-4-carboxylate (6.5 g) as a viscous oil contaminated with 5-fluoro-4iodopyridin-3-amine. The impure material was taken into the next reaction as follows. $\mathrm{PtO}_{2}(1.58 \mathrm{~g}, 6.96 \mathrm{mmol})$ 
was suspended in nitrogen degassed triflurorethanol and tert-butyl $(2 \mathrm{R}, 5 \mathrm{~S})-2-((3-a m i n o-5-f l u o r o p y r i d i n-4-$ yl)ethynyl)-5-(((tert-butyldimethylsilyl)oxy)methyl)morpholine-4-carboxylate $(6.5 \mathrm{~g}, 14 \mathrm{mmol})$ ( $50 \%$ pure $)$ was dissolved in nitrogen degassed trifluorethanol and added to the suspension of $\mathrm{PtO}_{2}$, total trifluorethanol $280 \mathrm{ml}$. The reaction was evacuated and backfilled with hydrogen and shaken on the a Parr at 50 psi hydrogen for 48 h. The reaction was degassed with nitrogen, filtered through celite and the solvent removed in vacuo. Purification on silica gel, eluting with a gradient of o to $100 \%$ EtOAc in hexanes, afforded the title compound ( $2.1 \mathrm{~g}, 24 \%)$ as a white solid. ${ }^{1} \mathrm{H}$ NMR (50o MHz, DMSO-d6) $\delta 7.79(\mathrm{~s}, 1 \mathrm{H}), 7.63(\mathrm{~s}, 1 \mathrm{H}), 5.46(\mathrm{~s}, 2 \mathrm{H}), 3.92(\mathrm{~d}, \mathrm{~J}=11.7 \mathrm{~Hz}, 1 \mathrm{H}), 3.85$ $3.67(\mathrm{~m}, 3 \mathrm{H}), 3.56-3.50(\mathrm{~m}, 1 \mathrm{H}), 3.44(\mathrm{dd}, \mathrm{J}=2.8,11.7 \mathrm{~Hz}, 1 \mathrm{H}), 3.32(\mathrm{~s}, 1 \mathrm{H}), 3.30-3.19(\mathrm{br} \mathrm{m}, 1 \mathrm{H}), 2.73-2.54(\mathrm{~m}$, $2 \mathrm{H}), 1.63-1.47(\mathrm{~m}, 2 \mathrm{H}), 1.40(\mathrm{~s}, 9 \mathrm{H}), 0.87(\mathrm{~s}, 9 \mathrm{H}), 0.06(\mathrm{~s}, 6 \mathrm{H})$; MS (ESI): $m / z=470.5\left(\mathrm{MH}^{+}\right), 97 \%$ pure by LCMS.<smiles>O=C(Nc1cncc(F)c1CC[C@H]1CO[C@H](C(=O)O)[C@H](CO)C1)c1ccccc1</smiles>

tert-Butyl (2R,5R)-2-(2-(3-(((benzyloxy)carbonyl)amino)-5-fluoropyridin-4-yl)ethyl)-5(hydroxymethyl)morpholine-4-carboxylate (23)

$\mathrm{Cbz}-\mathrm{Cl}(806 \mu \mathrm{l}, 5.64 \mathrm{mmol})$ was added dropwise to a solution of tert-butyl $(2 \mathrm{R}, 5 \mathrm{~S})-2-(2-(3$-amino-5-fluoropyridin4-yl)ethyl)-5-(((tert-butyldimethylsilyl)oxy)methyl)morpholine-4-carboxylate (21) (1.0 g, $2.13 \mathrm{mmol})$ in pyridine (5 $\mathrm{ml}$ ) at $\mathrm{o}{ }^{\circ} \mathrm{C}$. The reaction was allowed to warm slowly to ambient temperature overnight. The reaction was quenched with water and the crude product was extracted with $\mathrm{CH}_{2} \mathrm{Cl}_{2}\left(\mathrm{x}_{3}\right)$. The combined organic fractions were washed with brine, dried over $\mathrm{Na}_{2} \mathrm{SO}_{4}$, and concentrated in vacuo. The crude residue was dissolved in THF (7 ml) and IM TBAF (4.26 ml, $4.26 \mathrm{mmol})$ in THF was added dropwise at ambient temperature. The resulting reaction was stirred at this temperature for $2 \mathrm{~h}$. The solution was diltuted with EtOAc then washed with water and brine dried over $\mathrm{MgSO}_{4}$, and concentrated in vacuo. Purification on silica gel, eluting with a gradient of o to $100 \% \mathrm{~A}$ to $\mathrm{B}\left(\mathrm{A}=\mathrm{CHCl}_{3}, \mathrm{~B}=7: 2: 1 \mathrm{CHCl}_{3}: \mathrm{EtOAc:MeOH}\right)$ afforded the title compound $(615 \mathrm{mg}, 59 \%)$ as a glassy solid. ${ }^{1} \mathrm{H}$ NMR (399 MHz, Chloroform-d) $\delta 9.05(\mathrm{~s}, 1 \mathrm{H}), 8.18(\mathrm{~s}, 1 \mathrm{H}), 8.03(\mathrm{~s}, 1 \mathrm{H}), 7.47-7.31\left(\mathrm{~m},{ }_{5} \mathrm{H}\right), 5.28$ - 5.16 (m, $\left.2 \mathrm{H}\right)$, $4.06-3.60(\mathrm{~m}, 5 \mathrm{H}), 3.52(\mathrm{dd}, \mathrm{J}=3.5,11.9 \mathrm{~Hz}, 1 \mathrm{H}), 3.22-3.10(\mathrm{~m}, 1 \mathrm{H}), 2.88-2.63(\mathrm{~m}, 3 \mathrm{H}), 1.91-1.64(\mathrm{~m}, 2 \mathrm{H}), 1.44(\mathrm{~s}$, $9 \mathrm{H})$; MS (ESI): $m / z=490.6\left(\mathrm{MH}^{+}\right), 82 \%$ pure by LCMS. 
<smiles>CC(C)(C)OC(=O)N1C[C@H](CCc2c(N)cncc2F)OC[C@H]1COC(=O)NCC(F)(F)F</smiles>

tert-Butyl (2R,5S)-2-(2-(3-amino-5-fluoropyridin-4-yl)ethyl)-5-(((2,2,2trifluoroethyl)carbamoyl)oxy)methyl)morpholine-4-carboxylate (25)

A solution of tert-butyl $\quad(2 \mathrm{R}, 5 \mathrm{R})-2-(2-(3-((($ benzyloxy$)$ carbonyl)amino)-5-fluoropyridin-4-yl)ethyl)-5(hydroxymethyl)morpholine-4-carboxylate (23) (652 mg, $1.33 \mathrm{mmol}$ ) and CDI (270 mg, $1.67 \mathrm{mmol})$ in pyridine (7 $\mathrm{ml}$ ) was heated at $6 \mathrm{o}^{\circ} \mathrm{C}$ for $90 \mathrm{~min} .2,2,2$-Trifluoroethylamine $(2.09 \mathrm{ml}, 26.6 \mathrm{mmol})$ was added and the reaction heated at $60{ }^{\circ} \mathrm{C}$ overnight. The solution was diltuted with EtOAc then washed with water and brine, then dried over $\mathrm{MgSO}_{4}$ and concentrated in vacuo. Purification on silica gel, eluting with a gradient of o to 60 \% EtOAc in hexanes, afforded $402 \mathrm{mg}$ of tert-butyl $(2 \mathrm{R}, 5 \mathrm{~S})-2-(2-(3-(($ benzyloxy)carbonyl)amino)-5-fluoropyridin-4-yl)ethyl)5-((((2,2,2-trifluoroethyl)carbamoyl)oxy)methyl)morpholine-4-carboxylate. This material was dissolved in nitrogen degassed EtOH and added to a suspension of $10 \% \mathrm{Pd} / \mathrm{C}$ (6omg) in EtOH, total EtOH (10 ml). The reaction was evacuated and backfilled with hydrogen and stirred overnight under a balloon of hydrogen. The reaction was evacuated and backfilled with nitrogen and filtered through a pad of celite. The solvent was removed in vacuo to afford the title compound $(286 \mathrm{mg}, 45 \%)$ as a foam. ${ }^{1} \mathrm{H}$ NMR (399 MHz, Chloroform-d) ? $7.86(\mathrm{~d}, \mathrm{~J}=2.4 \mathrm{~Hz}, 1 \mathrm{H}), 7.84(\mathrm{~s}, 1 \mathrm{H}), 5.18-5.00(\mathrm{~m}, 1 \mathrm{H}), 4.45-3.58(\mathrm{~m}, 11 \mathrm{H}), 3.33-3.20(\mathrm{~m}, 1 \mathrm{H}), 2.89-2.62(\mathrm{~m}$, 2H), $1.79-1.67(\mathrm{~m}, 2 \mathrm{H}), 1.44(\mathrm{~s}, 9 \mathrm{H}) ; \mathrm{MS}(\mathrm{ESI}): \mathrm{m} / \mathrm{z}=481.6\left(\mathrm{MH}^{+}\right),{ }_{76 \%}$ pure by LCMS.

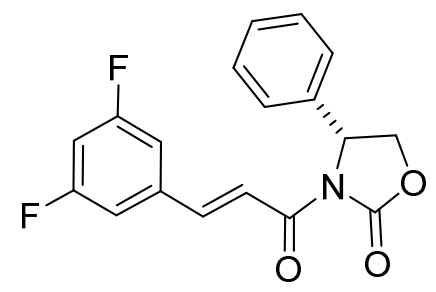

(R,E)-3-(3-(3,5-Difluorophenyl)acryloyl)-4-phenyloxazolidin-2-one (32) 
A $2.5 \mathrm{M}$ solution of ${ }^{\mathrm{n}} \mathrm{BuLi}$ in hexanes $(28.6 \mathrm{ml}, 71.5 \mathrm{mmol})$ was added dropwise to a solution of (R)-4phenyloxazolidin-2-one $(11.7 \mathrm{~g}, 71.5 \mathrm{mmol})$ in $\mathrm{THF}(400 \mathrm{ml})$ at $-10{ }^{\circ} \mathrm{C}$ and the resulting solution stirred at this temperature for $10 \mathrm{~min}$. A solution of (E)-3-(3,5-difluorophenyl)acryloyl chloride (14.5 g, $71.5 \mathrm{mmol})$ in THF (100 ml) was added dropwise and the resulting reaction stirred at $0^{\circ} \mathrm{C}$ for $30 \mathrm{~min}$. The reaction was quenched with $20 \%$ aq. $\mathrm{NH}_{4} \mathrm{Cl}$, and the crude product was extracted with EtOAc $\left(\mathrm{x}_{3}\right)$. The combined organic fractions washed with water, sat. aq. $\mathrm{NaHCO}_{3}$ and brine, dried over $\mathrm{MgSO}_{4}$, and concentrated in vacuo. Purification on silica gel, eluting with a gradient of o to $50 \%$ A to $\mathrm{B}\left(\mathrm{A}=1: 1\right.$ hexanes: $\left.\mathrm{CHCl}_{3}, \mathrm{~B}=\mathrm{EtOAc}\right)$ afforded the title compound (20 g, $86 \%$ ) as a solid. ${ }^{1} \mathrm{H}$ NMR (399 MHz, Chloroform-d) $\delta 7.91(\mathrm{~d}, \mathrm{~J}=15.7 \mathrm{~Hz}, 1 \mathrm{H}), 7.64(\mathrm{~d}, \mathrm{~J}=15.7 \mathrm{~Hz}, 1 \mathrm{H}), 7.46-7.32$ $\left(\mathrm{m},{ }_{5} \mathrm{H}\right), 7.15-7.03(\mathrm{~m}, 2 \mathrm{H}), 6.84(\mathrm{tt}, \mathrm{J}=2.3,8.7 \mathrm{~Hz}, 1 \mathrm{H}), 5.55(\mathrm{dd}, \mathrm{J}=3.9,8.7 \mathrm{~Hz}, 1 \mathrm{H}), 4.76(\mathrm{t}, \mathrm{J}=8.8 \mathrm{~Hz}, 1 \mathrm{H}), 4.35$ (dd, J = 3.9, 8.9 Hz, $1 \mathrm{H})$; MS (ESI): $m / z=330.3\left(\mathrm{MH}^{+}\right)$, $96 \%$ pure by LCMS.

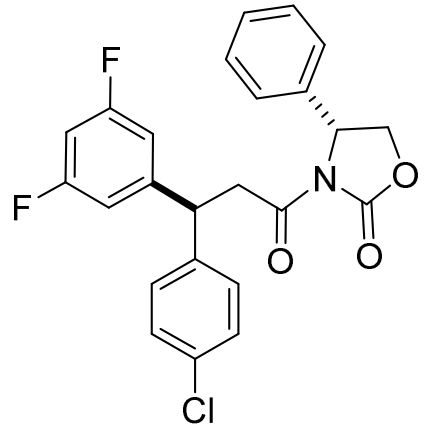

(R)-3-((S)-3-(4-chlorophenyl)-3-(3,5-difluorophenyl)propanoyl)-4-phenyloxazolidin-2-one (34)

A 1 M solution of (4-Chlorophenyl)magnesium bromide in THF $(76 \mathrm{ml}, 76 \mathrm{mmol})$ was added to $\mathrm{CuBr} \mathrm{SMe}_{2}(15.6$ g, $76 \mathrm{mmol}$ ) in THF (100 ml) at $-40{ }^{\circ} \mathrm{C}$. A solution of (R,E)-3-(3-(3,5-difluorophenyl)acryloyl)-4-phenyloxazolidin2-one (32) (10.0 g, $30.4 \mathrm{mmol})$ in THF (100 ml) was added dropwise and the resulting reaction stirred at $-40{ }^{\circ} \mathrm{C}$ for $1.5 \mathrm{~h}$, then allowed to warm slowly to ambient temperature. The reaction was quenched with $20 \%$ aq. $\mathrm{NH}_{4} \mathrm{Cl}$, and the crude product was extracted with EtOAc (x3). The combined organic fractions washed with water and brine, dried over $\mathrm{MgSO}_{4}$, and concentrated in vacuo. Purification on silica gel, eluting with a gradient of o to $50 \% \mathrm{~A}$ to B (A = 1:1 hexanes: $\left.\mathrm{CHCl}_{3}, \mathrm{~B}=\mathrm{EtOAc}\right)$ afforded the title compound (13.6 g, $100 \%$ ) as a solid. ${ }^{1} \mathrm{H}$ NMR (399 MHz, Chloroform-d) $\delta 7.35-7.16\left(\mathrm{~m},{ }_{5} \mathrm{H}\right), 7.18-7.04(\mathrm{~m}, 4 \mathrm{H}), 6.79-6.69(\mathrm{~m}, 2 \mathrm{H}), 6.63(\mathrm{tt}, \mathrm{J}=2.3,8.9 \mathrm{~Hz}, 1 \mathrm{H}), 5.36(\mathrm{dd}$, $J=3.9,8.7 \mathrm{~Hz}, 1 \mathrm{H}), 4.67(\mathrm{t}, \mathrm{J}=8.8 \mathrm{~Hz}, 1 \mathrm{H}), 4.53(\mathrm{t}, \mathrm{J}=7.7 \mathrm{~Hz}, 1 \mathrm{H}), 4.25(\mathrm{dd}, \mathrm{J}=3.9,8.9 \mathrm{~Hz}, 1 \mathrm{H}), 3.8 \mathrm{o}(\mathrm{dd}, \mathrm{J}=7.4$, $16.9 \mathrm{~Hz}, 1 \mathrm{H}), 3.58(\mathrm{dd}, \mathrm{J}=8.1,16.9 \mathrm{~Hz}, 1 \mathrm{H})$; MS (ESI): $m / z=442.4\left(\mathrm{MH}^{+}\right), 88 \%$ pure by LCMS. 


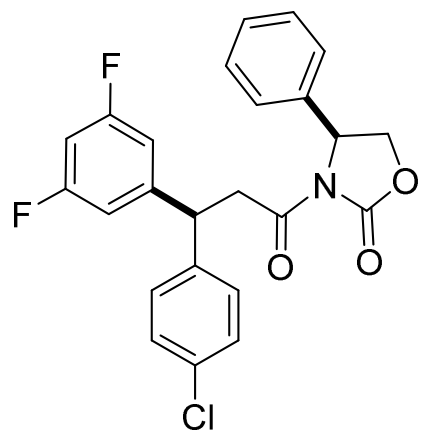

(S)-3-((S)-3-(4-chlorophenyl)-3-(3,5-difluorophenyl)propanoyl)-4-phenyloxazolidin-2-one (36)

A solution of aq. $35 \% \mathrm{H}_{2} \mathrm{O}_{2}(5.15 \mathrm{ml}, 58.8 \mathrm{mmol})$ then solid $\mathrm{LiOH}(705 \mathrm{mg}, 29.4 \mathrm{mmol})$ were added to a solution of (R)-3-((S)-3-(4-chlorophenyl)-3-(3,5-difluorophenyl)propanoyl)-4-phenyloxazolidin-2-one (34) (6.50 g, 14.7 mmol) in THF: $\mathrm{H}_{2} \mathrm{O}$ 3:1 $(120 \mathrm{ml})$ at o ${ }^{\circ} \mathrm{C}$. The reaction was stirred at this temperature for $30 \mathrm{~min}$. A solution of $\mathrm{Na}_{2} \mathrm{SO}_{3}(7.42 \mathrm{~g}, 58.8 \mathrm{mmol})$ in $\mathrm{H}_{2} \mathrm{O}$ was added followed by $0.5 \mathrm{M} \mathrm{NaHCO}_{3}(147 \mathrm{ml}, 73.6 \mathrm{mmol})$ and the resulting reaction stirred for $5 \mathrm{~min}$. The THF was removed in vacuo and the residue diluted with water and washed with $\mathrm{CH}_{2} \mathrm{Cl}_{2}\left(\mathrm{x}_{3}\right)$. The aqueous layer was acidified with $6 \mathrm{M} \mathrm{HCl}$ and the crude product was extracted with EtOAc $\left(\mathrm{x}_{3}\right)$. The combined organic fractions were dried over $\mathrm{MgSO}_{4}$, and concentrated in vacuo to afford (S)-3-(4chlorophenyl)-3-(3,5-difluorophenyl)propanoic acid as a solid. The crude acid was dissolved in $\mathrm{CH}_{2} \mathrm{Cl}_{2}$ (50 ml) and $\mathrm{SO}_{2} \mathrm{Cl}_{2}(2.88 \mathrm{ml}, 39.4 \mathrm{mmol})$ was added. The resulting reaction was heated at reflux for $4 \mathrm{~h}$. The solvent was removed in vacuo to afford (S)-3-(4-chlorophenyl)-3-(3,5-difluorophenyl)propanoyl chloride as an oil, used crude in the following reaction. A $2.5 \mathrm{M}$ solution of ${ }^{\mathrm{n}} \mathrm{BuLi}$ in hexanes $(5.25 \mathrm{ml}, 13.1 \mathrm{mmol})$ was added dropwise to a solution of (S)-4-phenyloxazolidin-2-one $(2.14 \mathrm{~g}, 13.1 \mathrm{mmol})$ in THF $(9 \mathrm{O} \mathrm{ml})$ at $-10{ }^{\circ} \mathrm{C}$ and the resulting solution stirred at this temperature for $10 \mathrm{~min}$. The crude acid chloride isolated above was dissolved in THF (6o ml) and added dropwise and the resulting reaction stirred at $0^{\circ} \mathrm{C}$ for $30 \mathrm{~min}$. The reaction was quenched with $20 \%$ aq. $\mathrm{NH}_{4} \mathrm{Cl}$, and the crude product was extracted with EtOAc $\left(\mathrm{x}_{3}\right)$. The combined organic fractions washed with water, sat. aq. $\mathrm{NaHCO}_{3}$ and brine, dried over $\mathrm{MgSO}_{4}$, and concentrated in vacuo. Purification on silica gel, eluting with a gradient of o to $50 \% \mathrm{~A}$ to $\mathrm{B}\left(\mathrm{A}=1: 1\right.$ hexanes: $\left.\mathrm{CHCl}_{3}, \mathrm{~B}=\mathrm{EtOAc}\right)$ afforded the title compound $(4.7 \mathrm{~g}, 81 \%)$ as a solid. ${ }^{1} \mathrm{H}$ NMR (399 MHz, Chloroform-d) $\delta 7.34-7.28(\mathrm{~m}, 3 \mathrm{H}), 7.26-7.18(\mathrm{~m}, 2 \mathrm{H}), 7.18-7.05(\mathrm{~m}, 4 \mathrm{H}), 6.77-$ $6.64(\mathrm{~m}, 2 \mathrm{H}), 6.60(\mathrm{tt}, \mathrm{J}=2.3,8.8 \mathrm{~Hz}, 1 \mathrm{H}), 5.34(\mathrm{dd}, \mathrm{J}=3.9,8.7 \mathrm{~Hz}, 1 \mathrm{H}), 4.65(\mathrm{t}, \mathrm{J}=8.9 \mathrm{~Hz}, 1 \mathrm{H}), 4.55(\mathrm{t}, \mathrm{J}=7.6 \mathrm{~Hz}$, $1 \mathrm{H}), 4.26(\mathrm{dd}, \mathrm{J}=4.0,8.9 \mathrm{~Hz}, 1 \mathrm{H}), 3.87-3.49(\mathrm{~m}, 2 \mathrm{H})$. 


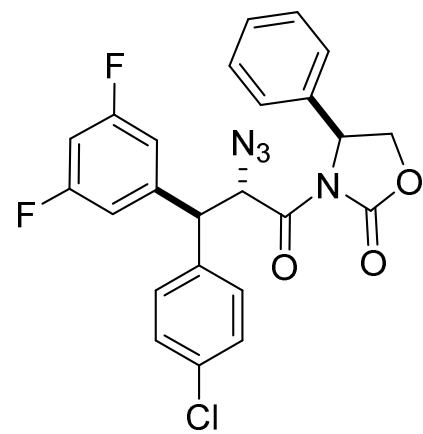

(S)-3-((2S,3S)-2-azido-3-(4-chlorophenyl)-3-(3,5-difluorophenyl)propanoyl)-4-phenyloxazolidin-2-one (38) A solution of (S)-3-((S)-3-(4-chlorophenyl)-3-(3,5-difluorophenyl)propanoyl)-4-phenyloxazolidin-2-one (36) (4.70 $\mathrm{g}$, $10.6 \mathrm{mmol}$ ) in THF(30 ml) was added dropwise to a $1 \mathrm{M}$ solution of NaHMDS in THF (11.7 ml, $11.7 \mathrm{mmol}$ ) at -78 ${ }^{\circ} \mathrm{C}$. The resulting reaction was stirred at this temperature for $30 \mathrm{~min}$. Solid trisylazide $(4.28 \mathrm{~g}, 13.8 \mathrm{mmol})$ was added in one portion and the reaction stirred for $2 \mathrm{~min}$, then acetic acid $(3.65 \mathrm{ml}, 63.8 \mathrm{mmol})$ and tetramethylamonium acetate $(5.67 \mathrm{~g}, 42.5 \mathrm{mmol})$ were added. The cooling bath was removed and the reaction stirred at ambient temperature for $4 \mathrm{~h}$. The reaction was quenched with brine and the crude product was extracted with EtOAc $\left(\mathrm{x}_{3}\right)$. The combined organic fractions washed with water, sat. aq. $\mathrm{NaHCO}_{3}$ and brine, dried over $\mathrm{MgSO}_{4}$, and concentrated in vacuo. Purification on silica gel, eluting with a gradient of o to $40 \%$ EtOAc in hexanes, afforded the title compound ( $3.23 \mathrm{~g}, 63 \%$ ) as a white solid. ${ }^{1} \mathrm{H}$ NMR (399 MHz, Chloroform-d) $\delta 7.44$ $7.33(\mathrm{~m}, 3 \mathrm{H}), 7.32-7.27(\mathrm{~m}, 2 \mathrm{H}), 7.27-7.25(\mathrm{~m}, 1 \mathrm{H}), 7.25-7.23(\mathrm{~m}, 1 \mathrm{H}), 7.23-7.17(\mathrm{~m}, 2 \mathrm{H}), 6.95-6.85(\mathrm{~m}, 2 \mathrm{H})$, $6.73(\mathrm{tt}, \mathrm{J}=2.2,8.8 \mathrm{~Hz}, 1 \mathrm{H}), 5.98(\mathrm{~d}, \mathrm{~J}=11.1 \mathrm{~Hz}, 1 \mathrm{H}), 5.13(\mathrm{dd}, \mathrm{J}=3.8,8.6 \mathrm{~Hz}, 1 \mathrm{H}), 4.50-4.36(\mathrm{~m}, 2 \mathrm{H}), 4.23(\mathrm{dd}, \mathrm{J}=$ 3.8, 9.0 Hz, $1 \mathrm{H})$; MS (ESI): poor ionization, 95\% pure by LCMS.<smiles>N#CC(C(=O)O)C(c1ccc(Cl)cc1)c1cc(F)cc(F)c1</smiles>

\section{(2S,3S)-2-azido-3-(4-chlorophenyl)-3-(3,5-difluorophenyl)propanoic acid (4o)}

A solution of aq. $35 \% \mathrm{H}_{2} \mathrm{O}_{2}(2.34 \mathrm{ml}, 26.8 \mathrm{mmol})$ then solid $\mathrm{LiOH}(320 \mathrm{mg}, 13.4 \mathrm{mmol})$ were added to a solution 
(3.23 g, $6.69 \mathrm{mmol})$ in THF: $\mathrm{H}_{2} \mathrm{O}$ 3:1 $(60 \mathrm{ml})$ at $\mathrm{o}^{\circ} \mathrm{C}$. The reaction was stirred at this temperature for $30 \mathrm{~min}$. A solution of $\mathrm{Na}_{2} \mathrm{SO}_{3}(3.37 \mathrm{~g}, 26.8 \mathrm{mmol})$ in $\mathrm{H}_{2} \mathrm{O}$ was added followed by $0.5 \mathrm{M} \mathrm{NaHCO}_{3}(66.5 \mathrm{ml}, 33.2 \mathrm{mmol})$ and the resulting reaction stirred for $5 \mathrm{~min}$. The THF was removed in vacuo and the residue diluted with water and washed with $\mathrm{CH}_{2} \mathrm{Cl}_{2}\left(\mathrm{x}_{3}\right)$. The aqueous layer was acidified with $6 \mathrm{M} \mathrm{HCl}$ and the crude product was extracted with EtOAc $\left(\mathrm{x}_{3}\right)$. The combined organic fractions were dried over $\mathrm{MgSO}_{4}$, and concentrated in vacuo to afford the title compound (2.26 g, $100 \%$ ) as a white solid. ${ }^{1} \mathrm{H}$ NMR (399 MHz, Chloroform-d) $\delta 7.33-7.29(\mathrm{~m}, 2 \mathrm{H}), 7.22$ - 7.17 (m, 2H), $6.90-6.82(\mathrm{~m}, 2 \mathrm{H}), 6.73(\mathrm{tt}, \mathrm{J}=2.3,8.8 \mathrm{~Hz}, 1 \mathrm{H}), 4.53-4.45(\mathrm{~m}, 2 \mathrm{H})$.<smiles>N[C@H](C(=O)Nc1cncc(F)c1CC[C@H]1CN[C@@H](COC(=O)NCC(F)(F)F)CO1)[C@@H](c1cc(F)cc(Cl)c1)c1ccc(F)cc1Cl</smiles>

((3S,6R)-6-(2-(3-((2S,3S)-2-Amino-3-(4-chlorophenyl)-3-(3,5-difluorophenyl)propanamido)-5-

fluoropyridin-4-yl)ethyl)morpholin-3-yl)methyl (2,2,2-trifluoroethyl)carbamate trihydrochloride (9t MK-8718)

$\mathrm{POCl}_{3}(35 \mu \mathrm{l}, 0.375 \mathrm{mmol})$ was added dropwise to a solution of $(2 \mathrm{~S}, 3 \mathrm{~S})$-2-azido-3-(4-chlorophenyl)-3-(3,5difluorophenyl)propanoic acid (40) (105 mg, $0.312 \mathrm{mmol}$ ) and tert-butyl (2R,5S)-2-(2-(3-amino-5-fluoropyridin-4yl)ethyl)-5-(((2,2,2-trifluoroethyl)carbamoyl)oxy)methyl)morpholine-4-carboxylate (25) (150 mg, 0.312 mmol) in pyridine $(0.5 \mathrm{ml})$ at $-10{ }^{\circ} \mathrm{C}$ and the reaction stirred for $30 \mathrm{~min}$ while allowing to warm to $0{ }^{\circ} \mathrm{C}$. The reaction was quenched with sat. aq. $\mathrm{NaHCO}_{3}$ and the crude product was extracted with $\mathrm{CH}_{2} \mathrm{Cl}_{2}\left(\mathrm{x}_{3}\right)$. The combined organic fractions washed with brine, dried over $\mathrm{Na}_{2} \mathrm{SO}_{4}$, and concentrated in vacuo. Purification on silica gel, eluting with a gradient of o to 70 \% EtOAc in hexanes, afforded $150 \mathrm{mg}$ of tert-butyl $\left({ }_{2} \mathrm{R}, 5 \mathrm{~S}\right)-2-\left(2-\left(3-\left({ }_{2} \mathrm{~S}, 3 \mathrm{~S}\right)-2-\right.\right.$ azido-3-(4chlorophenyl)-3-(3,5-difluorophenyl)propanamido)-5-fluoropyridin-4-yl)ethyl)-5-((((2,2,2-

trifluoroethyl)carbamoyl)oxy)methyl)morpholine-4-carboxylate. This compond (150 mg, $0.187 \mathrm{mmol}$ ) and $\mathrm{PPh}_{3}$ (73.8 mg, $0.281 \mathrm{mmol}$ ) were heated at reflux in 4:1 THF: $\mathrm{H}_{2} \mathrm{O}(5 \mathrm{ml})$ overnight. The solvent was removed in vacuo and purification on silica gel, eluting with a gradient of o to $10 \% \mathrm{MeOH}$ in $\mathrm{CHCl}_{3}$, afforded $136 \mathrm{mg}$ of tert-butyl (2R,5S)-2-(2-(3-((2S,3S)-2-amino-3-(4-chlorophenyl)-3-(3,5-difluorophenyl)propanamido)-5-fluoropyridin-4yl)ethyl)-5-(((2,2,2-trifluoroethyl)carbamoyl)oxy)methyl)morpholine-4-carboxylate. This material was dissolved 
$4 \mathrm{M} \mathrm{HCl}$ in dioxane $(1 \mathrm{ml})$ and stirred for 1 hour. The solvent was removed in vacuo to afford the title compound (59 mg, 55 \%) as a white solid. ${ }^{1} \mathrm{H}$ NMR (6oo MHz, DMSO-d6) $\delta 8.27(\mathrm{~s}, 1 \mathrm{H}), 8.08(\mathrm{~s}, 1 \mathrm{H}), 7.92-7.86(\mathrm{~m}, 1 \mathrm{H}), 7.41$ $(\mathrm{d}, \mathrm{J}=8.4 \mathrm{~Hz}, 2 \mathrm{H}), 7.33(\mathrm{~d}, \mathrm{~J}=8.4 \mathrm{~Hz}, 2 \mathrm{H}), 7.10(\mathrm{~d}, \mathrm{~J}=6.9 \mathrm{~Hz}, 2 \mathrm{H}), 7.05(\mathrm{t}, \mathrm{J}=9.3 \mathrm{~Hz}, 1 \mathrm{H}), 4.31(\mathrm{~d}, \mathrm{~J}=9.6 \mathrm{~Hz}, 1 \mathrm{H})$, $4.26(\mathrm{~d}, \mathrm{~J}=9.6 \mathrm{~Hz}, 1 \mathrm{H}), 4.20-4.10(\mathrm{~m}, 1 \mathrm{H}), 4.09-4.00(\mathrm{~m}, 1 \mathrm{H}), 3.82-3.7 \mathrm{o}(\mathrm{m}, 2 \mathrm{H}), 3.65(\mathrm{~d}, \mathrm{~J}=11.8 \mathrm{~Hz}, 1 \mathrm{H}), 3.52$ $(\mathrm{d}, \mathrm{J}=8.8 \mathrm{~Hz}, 1 \mathrm{H}), 3.22-3.16(\mathrm{~m}, 1 \mathrm{H}), 2.81-2.76(\mathrm{~m}, 1 \mathrm{H}), 2.61-2.49(\mathrm{~m}, 4 \mathrm{H}), 2.41-2.32(\mathrm{~m}, 1 \mathrm{H}), 1.61-1.51(\mathrm{~m}, 1 \mathrm{H})$, $1.41-1.31(\mathrm{~m}, 1 \mathrm{H}) ;{ }^{13} \mathrm{C}$ NMR (126 MHz, DMSO-d6) $\delta 174.3,164.2\left(\mathrm{~d}, \mathrm{~J}_{\mathrm{C}-\mathrm{F}}=14 \mathrm{~Hz}\right), 162.2\left(\mathrm{~d}, \mathrm{~J}_{\mathrm{C}-\mathrm{F}}=13 \mathrm{~Hz}\right), 159.8,157.6$ $\left(d, J_{C-F}=53 \mathrm{~Hz}\right), 147.4\left(t, J_{C-F}=9 \mathrm{~Hz}\right), 143.8,141.3,135.7\left(d, J_{C-F}=24 \mathrm{~Hz}\right), 134.5\left(d, J_{C-F}=3 \mathrm{~Hz}\right), 133.1\left(d, J_{C-F}=14 \mathrm{~Hz}\right)$, 132.4, 131.0, $125.7\left(\mathrm{q}, \mathrm{J}_{\mathrm{C}-\mathrm{F}}=279 \mathrm{~Hz}\right), 112.9$ - $112.6(\mathrm{~m}), 102.8\left(\mathrm{t}, \mathrm{J}_{\mathrm{C}-\mathrm{F}}=26 \mathrm{~Hz}\right), 75.9,77.0,63.8,59.2,54.9,50.9,46.2,42.7$ $\left(\mathrm{q}, \mathrm{J}_{\mathrm{C}-\mathrm{F}}=33 \mathrm{~Hz}\right)$, 31.7, 20.4; Optical rotation: $[\alpha]_{\mathrm{D}}{ }^{25}+37.2$ (c 1.12, MeOH); HRMS: Calcd for $\mathrm{C}_{30} \mathrm{H}_{32} \mathrm{ClF}_{6} \mathrm{~N}_{5} \mathrm{O}_{4}(\mathrm{MH})+$ 674.1963, found 674.1950; 97\% pure by LCMS.

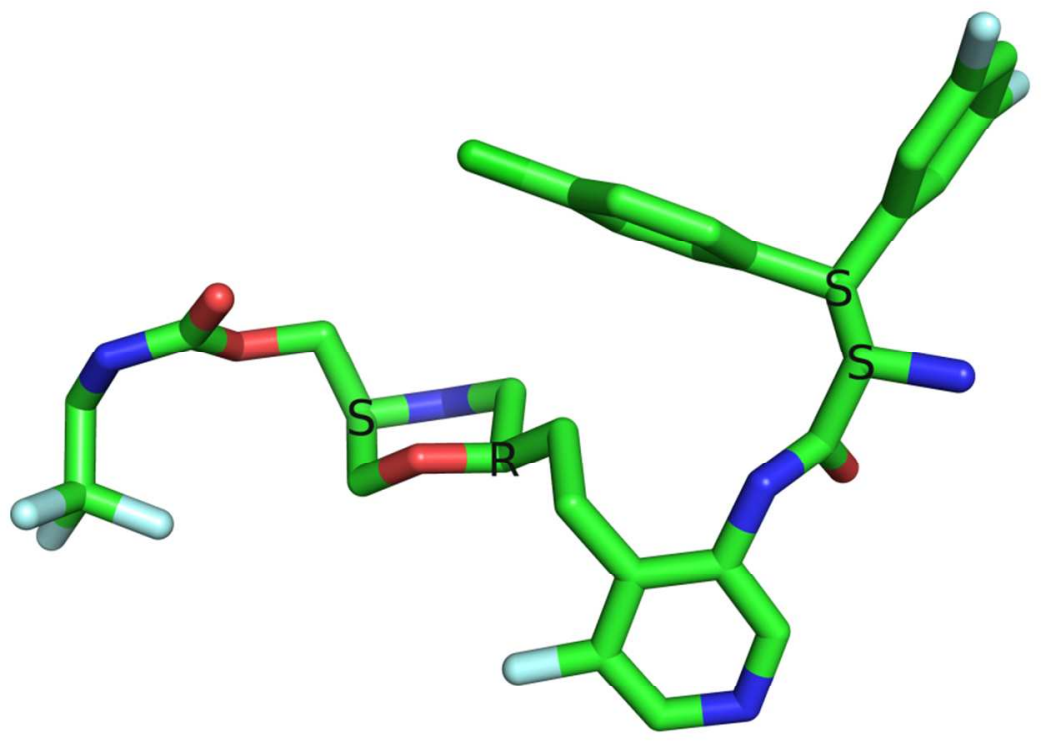

